\title{
MASTER
}

\section{Radioisotope Distribution Program Progress Report for January 1978}

E. Lamb

OAK RIDGE NATIONAL LABORATORY OPERATED BY UNION CARBIDE CORPORATION - FOR THE DEPARTMENT OF ENERGY 


\section{DISCLAIMER}

This report was prepared as an account of work sponsored by an agency of the United States Government. Neither the United States Government nor any agency Thereof, nor any of their employees, makes any warranty, express or implied, or assumes any legal liability or responsibility for the accuracy, completeness, or usefulness of any information, apparatus, product, or process disclosed, or represents that its use would not infringe privately owned rights. Reference herein to any specific commercial product, process, or service by trade name, trademark, manufacturer, or otherwise does not necessarily constitute or imply its endorsement, recommendation, or favoring by the United States Government or any agency thereof. The views and opinions of authors expressed herein do not necessarily state or reflect those of the United States Government or any agency thereof. 


\section{DISCLAIMER}

Portions of this document may be illegible in electronic image products. Images are produced from the best available original document. 
This report was prepared as an account of work sponsored by an agency of the United States Government. Neither the United States Government nor any agency thereof, nor any of their employees, contractors, subcontractors, or their employees, makes any warranty, express or implied, nor assumes any legal liability or responsibility for any third party's use or the results of such use of any information, apparatus, product or process disclosed in this report, nor represents that its use by such third party would not infringe privately owned rights. 
Contract No. W-7405-eng-26

OPERATIONS DIVISION

This report was prepared as an account of work sponsored by the United States Govemment. Neither the United States nor the United States Department of Energy, nor any of their employees, nor any of their contractors, subcontractors, or their employees, makes any warranty, express or implied, or assumes any legal liability or responsibility for the accuracy, completeness or usefulness of any information, apparatus, product or process disclosed, or represents that its use would not infringe privately owned rights.

RADIOISOTOPE DISTRIBUTION PROGRAM

PROGRESS REPORT FOR JANUARY 1978

... -

\author{
E. Lamb \\ Work Sponsored by \\ DOE Division of Biomedical and \\ Environmental Research
}

NOTICE This document contains information of a preliminary nature. It is subject to revision or correction and therefore does not represent a final report.

OAK RIDGE NATIONAL LABORATORY

Oak Ridge, Tennessee 37830

operated by

UNION CARBIDE CORPORATION

for the

DEPARTMENT OF ENERGY 


\section{THIS PAGE}

\section{WAS INTENTIONALLY \\ LEFT BLANK}


CONTENTS

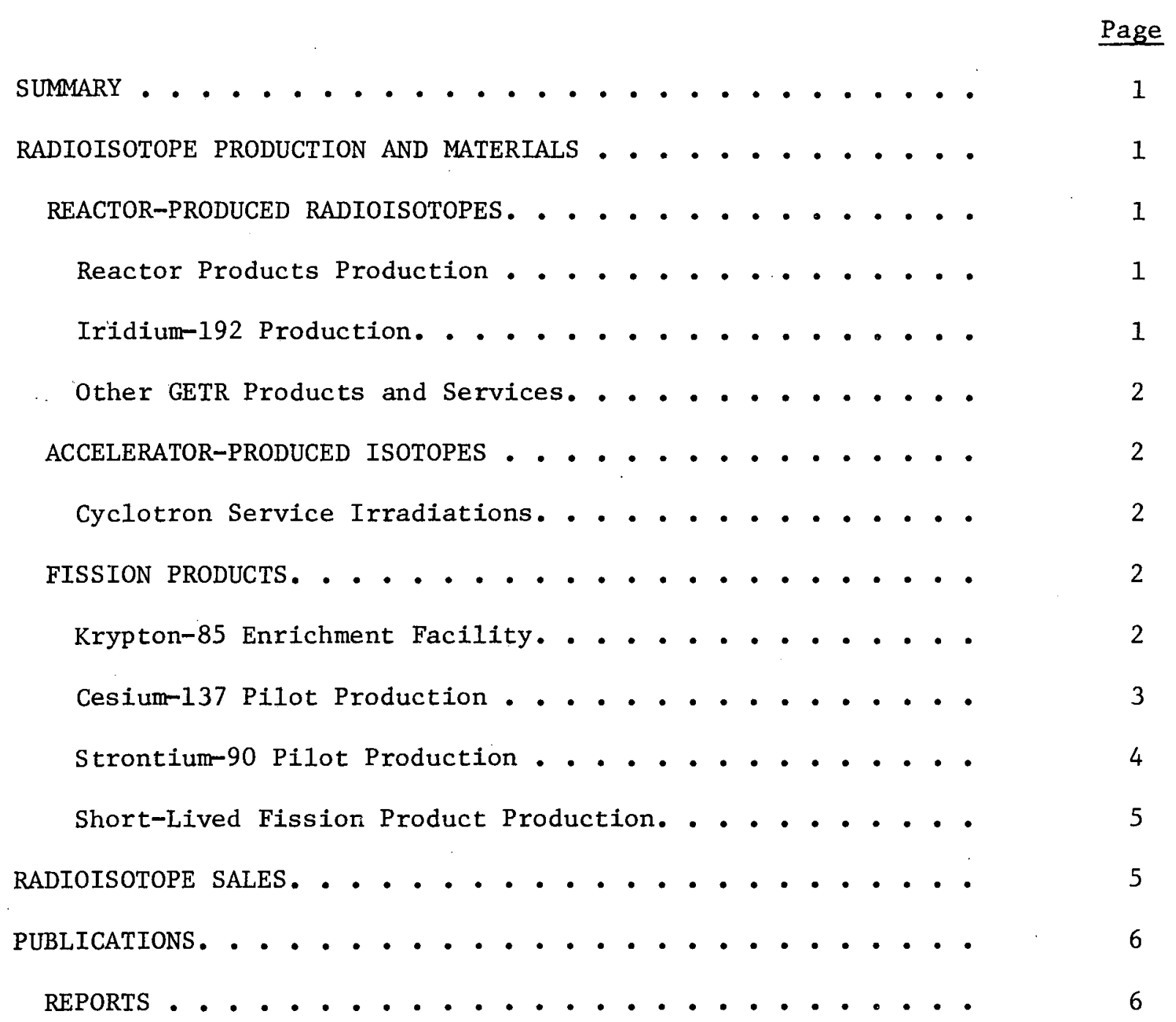




\section{SUMMARY}

Information is reported on new production, inventory status, operational problems, and radioisotope sales.

\section{RADIOISOTOPE PRODUCTION AND MATERIALS}

REACTOR-PRODUCED RADIOISOTOPES

Reactor Products Production (R. W. Schaich) (Production and Inventory Accounts)

$\frac{\text { Processed Units }}{\text { Radioisotope }} \frac{\text { Amount (mCi) }}{26}$
Calcium-47
-192 Production $(R$. W. Schaich)

Iridium-192 Production (R. W. Schaich)

A total of six customer irradiation units and five ORNL HFIR units (RF) were processed during the month of January 1978. Seven shipments containing 40,300 $\mathrm{Ci}$ of ${ }^{192} \mathrm{Ir}$ were made during this period. The average ${ }^{192}$ Ir yield for the various type irradiation units, pellet sizes, and HFIR cycles are as follows.

\begin{tabular}{|c|c|c|c|}
\hline $\begin{array}{l}\text { Type } \\
\text { Capsule } \\
\end{array}$ & Pellet Size & $\begin{array}{c}\text { HFIR } \\
\text { Cycles } \\
\end{array}$ & $\begin{array}{l}\text { Curies }{ }^{192} \mathrm{Ir} / \mathrm{gram} \\
\text { at HFIR Shutdown }\end{array}$ \\
\hline RG & $1 / 16^{\prime \prime}$ diam x $1 / 32^{\prime \prime}$ & 2 & 390 \\
\hline RG & $0.107^{\prime \prime}$ diam $\times 0.011^{\prime \prime}$ & 2 & 580 \\
\hline TO & $0.107^{\prime \prime}$ diam $\times 0.006^{\prime \prime}$ & 2 & 635 \\
\hline OT & $0.141^{\prime \prime}$ diam $\times 0.006^{\prime \prime}$ & 2 & 580 \\
\hline GB & $0.107^{\prime \prime}$ diam $\times 0.011^{\prime \prime}$ & 2 & 590 \\
\hline GB & $0.141^{\prime \prime}$ diam x 0.011" & 2 & 590 \\
\hline $\mathrm{RB}$ & $0.107^{\prime \prime}$ diam x $0.011^{\prime \prime}$ & 1 & 650 \\
\hline $\mathrm{RB}$ & $1 / 8^{\prime \prime}$ diam x 1/32" & 1 & 420 \\
\hline $\mathrm{RB}$ & $1 / 16 "$ diam $\times 1 / 32 "$ & 1 & 400 \\
\hline
\end{tabular}

These numbers will be refined as more units are processed. 
Other GETR Products and Services ( $E$. Lamb)

The General Electric Vallecitos Nuclear Center requested quotations on the irradiation of partially irradiated ${ }^{60} \mathrm{Co}$ capsules, the irradiation of two ${ }^{235} \mathrm{U}$ targets per week, and the irradiation of two GE-type iridium targets for one HFIR cycle for shipment as unprocessed units to GE. Estimates are being prepared for the requested quotations.

\section{ACCELERATOR-PRODUCED ISOTOPES}

Cyclotron Service Irradiations (M. R. Skidmore) (Production and Inventory Accounts)

January 1978 ORNL 86-Inch Cyclotron runs for ORNL and non-ORNL programs are given in Table 1 .

Table 1. Cyclotron Irradiations and Runs for January 1978

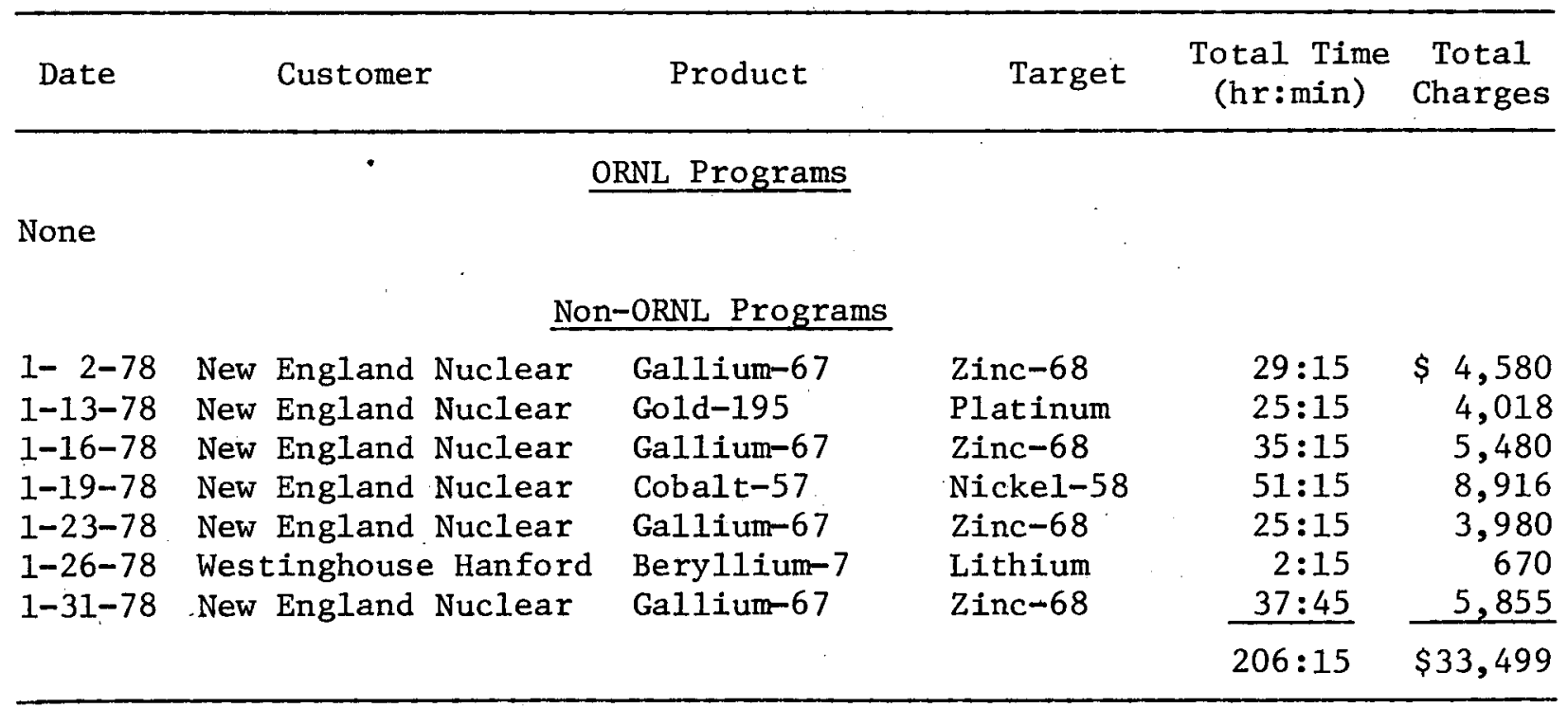

During the month of January, operations were interrupted three times. From January 5 th to 12 th carbon shields on the inner wall and the ion accelerating electrode were replaced. On January 17 th a cobalt-57 run was interrupted due to a malfunctioning plate current meter on the control console. On January $24 \mathrm{th}$ and $25 \mathrm{th}$, half of the rectifiers and one transformer in the ion filament power supply had to be replaced.

\section{FISSION PRODUCTS}

\section{Krypton-85 Enrichment Facility (R. W. Schaich)}

One ${ }^{85} \mathrm{Kr}$ enrichment column was operative during the month of January and the unit functioned according to design. The three columns in the south bank are shut down due to a shortage of manpower to check out the system. A tentative schedule calls for checking and loading the south bank in March 1978. 
Cesium-137 Pilot Production (R. W. Schaich)

(Production and Inventory Accounts)

1. Process Status

The ${ }^{137} \mathrm{Cs}$ processing equipment has been placed in standby status.

2. Operational Summary

Product Inventory

(Decay calculated through August 31, 1977)

Inventory Material

Cesium-137 chloride powder

Total Inventory Material
Amount (Ci)

29,860

29,860

Amount (Ci)

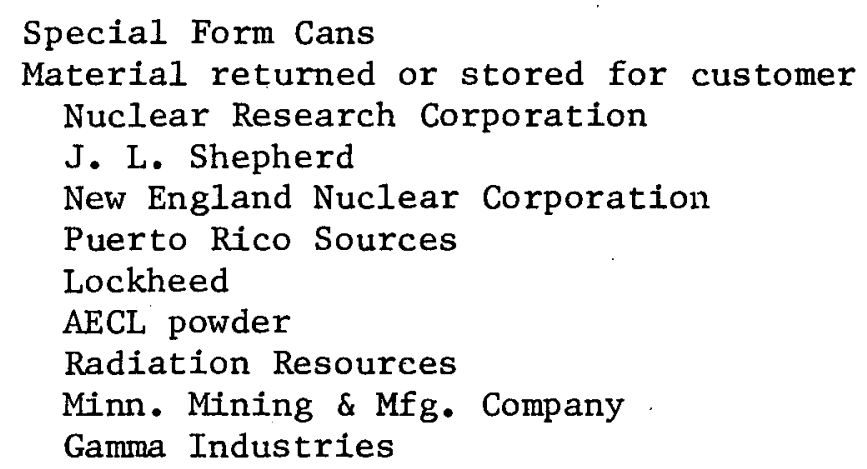

Total Non-Inventory Material

TOTAL INVENTORY AND NON-INVENTORY MATERIAL

$$
\begin{array}{r}
4,300 \\
0 \\
50,600 \\
2,500 \\
7,900 \\
19,600 \\
71,500 \\
19,800 \\
2,800 \\
8,400 \\
\hline 187,400 \\
\hline
\end{array}
$$

217,260

Fabrication Summary

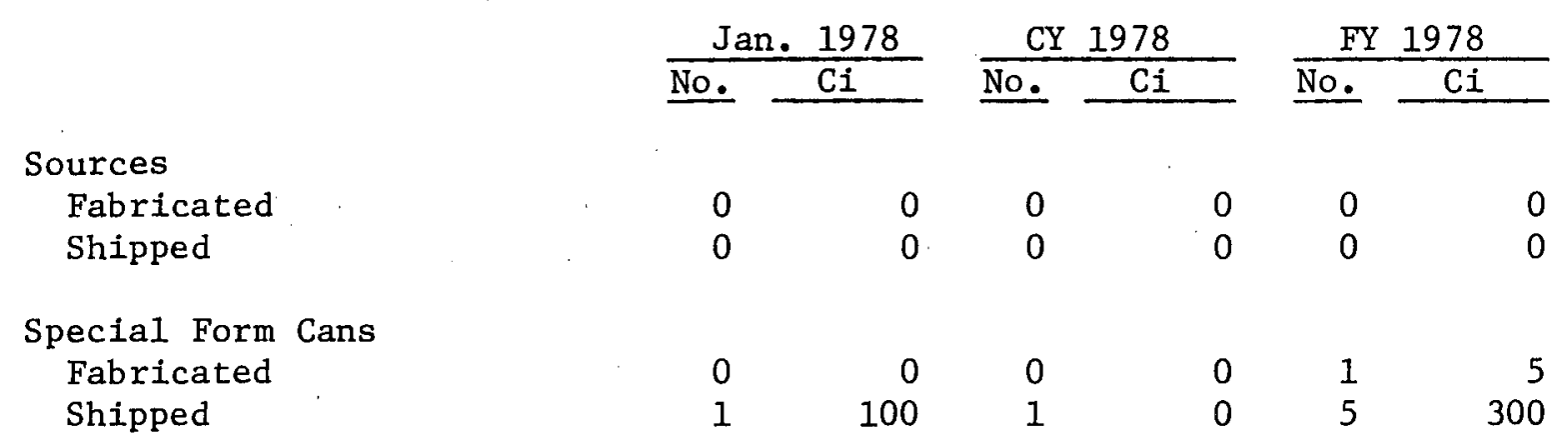

3. Current Orders

All orders on hand have been completed and the material placed into storage awaiting receipt of release for the material. 
Strontium-90 Pilot Production (R. W. Schaich)

(Production and Inventory Accounts)

1. Process Status

The ${ }^{90} \mathrm{Sr}$ source fabrication equipment has been placed in standby status.

Product Inventory

(Decay calculated through August 31, 1977)

Inventory Material

${ }^{90} \mathrm{Sr}$ titanate powder $( \pm 5 \%)$

Sources in fabrication

Stock powder cans

Stock solution
Amount (Ci)

0

0

3,325

200

3,525

Amount (Ci)

$\underline{\text { Non-Inventory Material }}$

Batch 26Sr-74RE

Calorimeter Standards

Weather Bureau source

SNAP-7B

SNAP-7C

SNAP-7D

SNAP material purchase ${ }^{a}$

AGN-4 Powder

Total Non-Inventory Material

TOTAL INVENTORY AND NON-INVENTORY MATERIAL
7,900

4,800

11,400

156,300

24,600

143,000

248,300

38,400

634,700

638,225

${ }^{a_{\text {Strontium-90 }}}$ purchased under DRRD program.

An inquiry has been received from Teledyne Energy Systems to fabricate three ${ }^{90} \mathrm{Sr}$ titanate units using the SNAP-7D material. This project can be accomplished by the end of 1978 .

Fabrication Summary

$\frac{\text { Jan. } 1978}{\text { No. } \frac{\mathrm{CY} 1978}{\mathrm{Ci}}} \stackrel{\text { FY } 1}{\text { No. } \frac{1978}{\mathrm{Ci}}}$

Sources

Fabricated

Shipped

$0 \quad 0 \quad 0$

$0 \quad 0$

0

Special Form Cans

Fabricated

Shipped

0

$0 \quad 0$

$0 \quad 0$

$\begin{array}{ll}0 & 0 \\ 0 & 0\end{array}$

0

0

0

0 
Short-Lived Fission Product Production (R. W. Schaich) (Production and Inventory Accounts)

The production of short-lived fission products is listed in the table below. Isotope Number of Batches Amount (Ci)

Xenon-133

4 2400

\section{RADIOISOTOPE SALES}

$$
\text { J. E. Ratledge }
$$

Mr. Robert Taylor of Monsanto Research Corporation visited Isotope Sales in January for discussion on americium-241.

Shipments made during the month that may be of interest are listed below:

Customer

Isotope

$\underline{\text { Amount }}$

\section{Large Quantities}

New England Nuclear Corporation Self-Powered Lighting, Ltd. Saunders-Roe Developments, England
Tritium Tritium

Tritium
$10,000 \mathrm{Ci}$ $3,000 \mathrm{Ci}$ $30,000 \mathrm{Ci}$

\section{Withdrawn Items}

Mine Safety Appliances Company

Technical Operations

Source Production and Equipment Company

Gamma Industries

Automation Industries

Gulf Nuclear Inc.
Iodine-131

Iridium-192

Iridium-192

Iridium-192

Iridium-192

Iridium-192
$150 \mathrm{mCi}$

$21,037 \mathrm{Ci}$

$9,334 \mathrm{Ci}$

$7,530 \mathrm{Ci}$

$11,314 \mathrm{Ci}$

$9,440 \mathrm{Ci}$

Items Used in Cooperative Programs

University of Southern California

Veterans Administration Hospital

University of Arizona
Platinum-195m

Platinum-195m

Platinum-195m
$10 \mathrm{mCi}$

$15 \mathrm{mCi}$

$5 \mathrm{mCi}$

The radioisotope sales and shipments for the first four months of fiscal year 1977 and fiscal year 1978 are given in Table 2. 
Table 2. Radioisotope Sales and Shipments

\begin{tabular}{lcc}
\hline \multicolumn{1}{c}{ Item } & $\begin{array}{c}10-1-76 \text { thru } \\
1-31-77\end{array}$ & $\begin{array}{c}10-1-77 \text { thru } \\
1-31-78\end{array}$ \\
\hline Inventory items & $\$ 102,985$ & $\$ 336,340$ \\
Major products & 36,399 & 150,695 \\
Radioisotope services & 61,507 & 55,558 \\
Cyclotron irradiations & 165,934 & 116,143 \\
Miscellaneous processed materials & 18,502 & 63,390 \\
Packing and shipping & 63,189 & 65,335 \\
\multicolumn{1}{c}{ Total } & $\$ 448,516$ & $\$ 787,461$ \\
Number of shipments & 792 & 788 \\
\hline
\end{tabular}

\section{PUBLICATIONS}

\section{REPORTS}

E. Lamb, Radioisotope Distribution Program Progress Report for December 1977, ORNL/TM-6244, Oak Ridge National Laboratory (February 1978). 
ORNL/TM-6347

INTERNAL DISTRIBUTION

1. F. N. Case

2. W. R. Cas to

3. J. A. $\operatorname{Cox}$

4. R. F. Hibbs

5. E. Lamb

6. H. H. Nichol

7. C. L. Ottinger

8. J. K. Poggenburg

9. H. Postma
10. M. E. Ramsey

11. J. E. Ratledge

12. C. R. Richmond

13. R. W. Schaich

14. M. R. Skidmore

15. M. J. Skinner

16-17. Central Research Library

18-19. Laboratory Records Department

20. Laboratory Records - RC

21. Document Reference Section

EXTERNAL DISTRIBUTION

22. B. J. Dropesky, LASL, Los Alamos, New Mexico

23-24. J. H. Jarrett, PNL, Richland Washington

25. D. K. Jones, Richland Operations Office, Richland, Washington

26. J. N. Maddox, DOE-DBER, Washington, D.C.

27. H. A. O'Brien, LASL, Los Alamos, New Mexico

28. F. J. Skozen (Krizek), Argonne Cancer Research Hospital, Chicago

29. L. G. Stang, Jx., BNL, New York

30. W. H. Weyzen, DOE-DBER, Washington, D.C.

31-32. R. W. Wood, DOE-DBER, Washington, D.C.

33. Donner Laboratory Library, Univ. of California, Berkeley, Calif., 94720

34. Research and Technical Support Division, ORO

35-36. Technical Information Center 